\title{
Public and Private Enforcement in European Union Food Law
}

\author{
Kai P. Purnhagen ${ }^{1,2 *}$ and Alexandra Molitorisová ${ }^{1,2}$ \\ ${ }^{1}$ Faculty of Life Sciences: Food, Nutrition and Health (Campus Kulmbach), University of Bayreuth, \\ Bayreuth, Germany and ${ }^{2}$ Faculty of Law, University of Bayreuth, Bayreuth, Germany \\ *Corresponding author. Email: kai.purnhagen@uni-bayreuth.de
}

\begin{abstract}
What type of enforcement is the most effective to punish violations of food law or to prevent them from occurring in the first place? This article examines the question of which mix of private and public enforcement exists in European Union (EU) food law and whether this mix corresponds to the recommendations of existing social science research. Based on this research, we contend that EU-determined enforcement mechanisms differ in effectiveness across Member States. New technologies have the potential to stimulate a novel mix of public and private enforcement tools at the EU and national levels.
\end{abstract}

Keywords: enforcement; EU law; food; food control

\section{Introduction}

In 2015, Bavarian media uncovered an outbreak of salmonella at the agricultural company Bayern-Ei. ${ }^{1}$ As a result of the outbreak, hundreds of consumers fell ill and at least one died. The structural problem was quickly found: the food control system seemed to be ill-suited. Therefore, the establishment of a new food control system was proposed. Discussions turned to whether and how to reform regulatory oversight of food business operations. ${ }^{2}$ Four years later, a similar event took place: in 2019, three deaths arose in the State of Hessen due to the consumption of Listeria-contaminated pizza salami from the Wilke company. ${ }^{3}$ The subsequent investigations revealed significant deficiencies in hygiene as well as further violations of law in the production and sales of the company. Again, food control exercised by public authorities was quickly named as the culprit and reforms were suggested. It seems that whenever problems occur in the food chain, food control authorities are singled out as the wrongdoers. Almost reflexively, they are restructured and given more or fewer tasks. It is seldom evident whether a lack of public control is a cause of the respective undesirable

\footnotetext{
${ }^{1}$ P Grüll, “Großteil der in Deutschland Erkrankten aus Bayern” (Süddeutsche Zeitung, 18 February 2021) <https://web.archive.org/web/20170305040805/http://www.br.de/nachrichten/bayern-ei-krankheitsfaelle-100. html> (last accessed 7 December 2021).

${ }^{2}$ See C Sebald, "Kontrollbehörde steht in der Kritik" (Süddeutsche Zeitung, 18 February 2021) <https://www. sueddeutsche.de/bayern/bayern-kblv-kritik-gutachten-gruene-1.5210223> (last accessed 7 December 2021).

3 "Wilke geht, der Fleischskandal bleibt" (Frankfurter Allgemeine, 29 March 2020) <https://www.faz.net/aktuell/ rhein-main/region-und-hessen/wilke-fleischskandal-weiter-fall-fuer-politik-und-justiz-16701778.html > (last accessed 7 December 2021).
}

(c) The Author(s), 2022. Published by Cambridge University Press. This is an Open Access article, distributed under the terms of the Creative Commons Attribution licence (https://creativecommons.org/licenses/by/4.0/), which permits unrestricted re-use, distribution, and reproduction in any medium, provided the original work is properly cited. 
situations and whether a reform of public control is the right reaction to remedy future violations of food law.

It is perhaps more pertinent to ask which type of enforcement can effectively punish violations of food law or prevent them from occurring in the first place. Like any decisionmakers, addressees of food law react to stimuli from the external and internal environments at the time of their decisions. Food business operators only comply with food law requirements if they are effectively urged to do so by external or internal stimuli. Law enforcement belongs to external stimuli. Jurisprudential literature differentiates four parameters of law enforcement: ${ }^{4}$

(1) The allocation of law enforcement powers to several institutions;

(2) The type of sanction (injunction, fee, penalty);

(3) The timing of enforcement (ex ante supervision or ex post enforcement);

(4) Centralised or decentralised enforcement.

Empirical and theoretical research illustrates that these parameters are equally important to ensuring the enforcement's effectiveness. ${ }^{5}$ This article concerns the first parameter. The question is whether it is more effective to entrust private actors (food business operators or consumers) with food law enforcement or to vest such powers in public actors. Past research has not treated the two as mutually exclusive alternatives. Rather, in other areas of law, such as competition law ${ }^{6}$ or consumer protection law, ${ }^{7}$ research has been predominantly concerned with the question of how to design the most efficient mix of private and public enforcement (ie to combine the best of all worlds). ${ }^{8}$ Admittedly, searching for an effective enforcement approach is a normative task. The determination of what is understood as "effective" depends on whether and how the enforcement costs are evaluated and how effectively private versus public enforcement deters food business operators from violations of the law. ${ }^{9}$ Furthermore, this article does not assume the existence of one "Idealtyp" mix of effective enforcement. Rather, what is "ideal" depends on several factors, such as the type of breach, its severity, the type of victim, etc.

Public enforcement is understood as the ex ante supervision and ex post enforcement by a public authority that is empowered by law to do so. ${ }^{10}$ Private enforcement is the enforcement of substantive law by subjects of private law. ${ }^{11}$ For this purpose, they can be endowed with

\footnotetext{
4 S Shavell, "The Optimal Structure of Law Enforcement" (1993) 36 Journal of Law and Economics 255, 257.

${ }^{5} \mathrm{R}$ van den Bergh, "Should Consumer Protection Law Be Publicly Enforced? An Economic Perspective on EC Regulation 2006/2004 and Its Implementation in the Consumer Protection Laws of the Member States" in W van Boom and M Loos (eds), Collective Enforcement of Consumer Law: Securing Compliance in Europe through Private Group Action and Public Authority Intervention (Zutphen, Europa Law Publishing 2007) pp 179, 182.

${ }^{6} \mathrm{~K}$ Hüschelrath and H Schweitzer (eds), Public and Private Enforcement of Competition Law in Europe. Legal and Economic Perspectives (Berlin, Springer 2014); R Koch, "Rechtsdurchsetzung im Kartellrecht: Public vs. Private Enforcement: Auf dem Weg zu einem Level Playing Field?” (2013) 68 Juristenzeitung 390, 398.

${ }^{7}$ See F Cafaggi and H Micklitz (eds), New Frontiers of Consumer Protection - The Interplay between Private and Public Enforcement (Cambridge, Intersentia 2009).

${ }^{8} \mathrm{R}$ van den Bergh and L Visscher, "The Preventive Function of Collective Actions for Damages in Consumer Law" (2008) 1 Erasmus Law Review 5; Cafaggi and Micklitz, supra, note 7, 38; C Hodges, "Objectives, Mechanisms and Policy Choices in Collective Enforcement and Redress" in J Steele and W van Boom (eds), Mass Justice: Challenges and Distribution (Cheltenham, Edward Elgar 2011) p 101.

${ }^{9}$ T Ackermann, "Unternehmenssteuerung durch finanzielle Sanktionen" (2015) 179 Zeitschrift für das gesamte Handelsrecht und Wirtschaftsrecht 538, 547.

${ }^{10}$ F Weber and M Faure, "The Interplay between Public and Private Enforcement in European Private Law: Law and Economics Perspective” (2015) 23 European Review of Private Law 525, 529.

11 ibid, 529.
} 
special rights, such as a privileged standing or a right to information. ${ }^{12}$ This article first takes stock of the situation. What is the mix of private and public enforcement in European Union (EU) food law? The article then presents research that has dealt with the optimal composition of such a mix in other areas of law and in economic research. In the final step, the article applies these findings to the current regulation of enforcement in EU food law. Based on this, the article presents a conclusion.

\section{Private and public enforcement in EU food law}

Regulation (EC) No 178/2002 13 (“General Food Law") lays down the basic system-building principles and rules of EU food law, including its enforcement. ${ }^{14} \mathrm{EU}$ food law enforcement entail elements of public and private kind: Article 17 of the General Food Law establishes a dual system of compliance control by food business operators and enforcement by Member States. First, according to Article 17(1) of the General Food Law, food business operators are primarily tasked with the control of compliance with food law. Second, Article 17(2) of the General Food Law provides that Member States have the duty to enforce and monitor compliance with food law as they "shall maintain a system of official controls". Article 17(2) of the General Food Law thus places the onus on Member States to ensure effective public enforcement. Moreover, Member States also have discretion to introduce "other activities as appropriate to the circumstances", such as measures facilitating private enforcement.

\section{Private and public enforcement in the General Food Law}

The first part of the dual system of enforcement under Article 17 of the General Food Law consists of an obligation of a food business operator to inform, withdraw or recall a product. ${ }^{15}$ The obligation arises when a food business operator "considers or has a reason to believe" that a foodstuff under its control is "not in compliance with the food safety requirements". ${ }^{16}$ While Article 19 of the General Food Law does not provide for private enforcement itself, it requires food business operators to have measures of private enforcement in place. This places private enforcement at a prominent position in the General Food Law since food business operators must also address the identified infringements (or reasonable suspicions thereof). Under certain conditions, food business operators must also inform competent authorities of the identified infringements, who must then adopt necessary measures. One could say that the enforcement regime of EU food law is based on private enforcement by food business operators flanked by public enforcement. This relationship is confirmed, for example, by Article 14 a) of Regulation (EU) 2017/62517 ("Control Regulation"), which provides that official controls must include "an examination of the controls that operators have put in place and of the results obtained". In the core area of EU food law (ie the General Food Law), private enforcement

\footnotetext{
${ }^{12}$ See Directive 2009/22/EC of the European Parliament and of the Council of 23 April 2009 on injunctions for the protection of consumers' interests (Codified version), OJ L 110/30.

${ }^{13}$ Regulation (EC) No 178/2002 of the European Parliament and of the Council of 28 January 2002 laying down the general principles and requirements of food law, establishing the European Food Safety Authority and laying down procedures in matters of food safety, OJ L 31/1.

${ }^{14}$ On the horizontal character of the General Food Law, see B van der Meulen, "The Structure of European Food Law" (2013) 2 Laws 69.

${ }^{15}$ Art 19 of the General Food Law.

${ }^{16}$ Art 19(1) of the General Food Law.

${ }^{17}$ Regulation (EU) 2017/625 of the European Parliament and of the Council of 15 March 2017 on official controls and other official activities performed to ensure the application of food and feed law, rules on animal health and welfare, plant health and plant protection products (Official Controls Regulation), OJ L 95/1.
} 
plays a considerable role. It is therefore surprising that in the case of food safety crises political reform efforts regularly target public control. Why is the improvement of food control primarily sought in the reform of public enforcement, even though the General Food Law seems to assume more effective enforcement by private entities?

\section{Private and public enforcement in specific areas of EU food law}

In more specific areas of EU food law, public enforcement is a dominating type of enforcement. Examples include authorisation procedures, such as those concerning genetically modified organisms (GMOs) ${ }^{18}$ novel foods ${ }^{19}$ and food additives, ${ }^{20}$ as well as nutrition and health claims on food. ${ }^{21}$ Another distinct area of EU food law (Directive (EU) 2019/633 on Unfair Trading Practices in Business-to-Business Relationships in the Agricultural and Food Supply Chain ("UTP Directive")) is based on a competition law enforcement regime that combines elements of both private and public enforcement. ${ }^{22}$ The third specific EU food law area encompasses private enforcement embodied in self-regulation regimes, such as standardisation and certification.

\section{a. Authorisations and enforcement}

GMO food law represents the most comprehensive public enforcement mechanism. Any placing on the market of a food intended to be used as a GMO is subject to authorisation according to Article 4(2) of Regulation (EC) No 1829/2003 and must fulfil the authorisation requirements. This allows the European Food Safety Authority/European Commission to sanction a breach of substantive law by not granting an authorisation before the market entry, arguably one of the most effective forms of public enforcement. Here, the asymmetry of information between the authority and the applicant - a serious problem of public enforcement - is weak. However, other problems arise: depending on their design, authorisation procedures may take years, ${ }^{23}$ and businesses and society may thus incur high costs. ${ }^{24}$ In particular, innovative small and medium-sized enterprises often cannot afford application costs ${ }^{25}$ and so cannot compete with larger enterprises. Consequently, society does not benefit from urgently needed innovations in the food sector. Moreover, if an authorisation procedure contains extra-legal, political elements, then the outcome of the process becomes unpredictable: even if an applicant has fulfilled the

\footnotetext{
${ }^{18}$ Regulation (EC) No 1829/2003 of the European Parliament and of the Council of 22 September 2003 on genetically modified food and feed, OJ L 268/1.

${ }^{19}$ Regulation (EU) 2015/2283 of the European Parliament and of the Council of 25 November 2015 on novel foods, amending Regulation (EU) No 1169/2011 of the European Parliament and of the Council and repealing Regulation (EC) No 258/97 of the European Parliament and of the Council and Commission Regulation (EC) No 1852/2001, OJ L 327/1.

${ }^{20}$ Regulation (EC) No 1333/2008 of the European Parliament and of the Council of 16 December 2008 on food additives, OJ L 354/16.

${ }^{21}$ Regulation (EC) No 1924/2006 of the European Parliament and of the Council of 20 December 2006 on nutrition and health claims made on foods, OJ L 404/9.

${ }^{22}$ Directive (EU) 2019/633 of the European Parliament and of the Council of 17 April 2019 on unfair trading practices in business-to-business relationships in the agricultural and food supply chain, PE/4/2019/REV/2, OJ L 111/59.

${ }^{23}$ R Smart, M Blum and J Wesseler, "Trends in Approval Times for Genetically Engineered Crops in the United States and the European Union" (2016) 68 Journal of Agricultural Economics 182.

${ }^{24}$ J Wesseler and D Zilberman, "The Economic Power of the Golden Rice Opposition” (2014) 19 Environment and Development Economics 724.

25 A Whelan, P Gutti and M Lema, "Gene Editing Regulation and Innovation Economics" (Frontiers of Bioengineering and Biotechnology, 15 April 2020) <https://doi.org/10.3389/fbioe.2020.00303> (last accessed 7 December 2021). See the GMO Register of the EU Commission <https://webgate.ec.europa.eu/dyna/gm register/index_en.cfm> (last accessed 14 December 2021).
} 
authorisation requirements, authorisation may not be granted. This generates an additional deterrent effect - a phenomenon well-known from GMO laws in Europe. The coronavirus pandemic illustrates that this de facto market foreclosure through effective enforcement is not just a mind game, but has developed into a tangible problem that requires an urgent fix. The fix quickly came six months into the pandemic when the approval requirements for certain GMO vaccines were partially suspended on the grounds that they prolong the authorisation process and stand in the way of innovations needed to combat the virus. ${ }^{26}$

\section{b. Unfair competition law and enforcement}

Unfair competition law has traditionally been an area of private enforcement ${ }^{27}$ as regards consumer-to-business (C2B) relationships. In EU food law, however, the UTP Directive concerning unfair commercial practices in business-to-business (B2B) relationships has changed this approach and put in place a public enforcement structure. ${ }^{28}$ According to the UTP Directive, each Member State must designate one or two authorities to enforce the prohibitions of unfair trading practices. Such authorities are competent to receive complaints submitted by suppliers, producers or their organisations. They may require buyers and suppliers to provide all necessary information to conduct investigations of prohibited trading practices. They may carry out unannounced on-site inspections. Finally, they may impose a fine, publish their decisions or not take any decision at all. It remains to be seen whether this will become the norm for other regulations governing supply chains beyond the UTP Directive. ${ }^{29}$

\section{c. Labelling, standardisation and certification and enforcement}

Food information law and the law governing private standards are enforced via private and public means, with an emphasis placed on private enforcement mechanisms. ${ }^{30}$ The system of private enforcement in food information law in the C2B sector is linked to the regime of unfair competition law by virtue of the wording of Article 7 of Regulation (EU) No 1169/2011 31 ("FIC"). Any breach of Article 7 FIC can be enforced by the imposition of an injunctive relief by qualified institutions of Member States according to Article 2 Directive 2009/22/EC. ${ }^{32}$ Other means of enforcement are subject to Member State legislation, which may provide for the employment of private enforcement mechanisms by providing business operators or consumers with a right to impose injunctive relief or claim compensation for a breach of unfair competition law before a court. ${ }^{33}$

\footnotetext{
${ }^{26}$ See Regulation (EU) 2020/1043 of the European Parliament and of the Council of 15 July 2020 on the conduct of clinical trials with and supply of medicinal products for human use containing or consisting of genetically modified organisms intended to treat or prevent coronavirus disease (COVID-19), PE/28/2020/REV/1, OJ L 231/12; on this topic, see J Wesseler and K Purnhagen, "Is the Covid-19 Pandemic a Game Changer in GMO Regulation?" (2020) 19(3) Eurochoices 49.

${ }^{27} \mathrm{See}$, eg, the comparative analysis of Member State legislation by B Keirsbilck, The New European Law of Unfair Commercial Practices and Competition Law (Oxford, Hart 2011) pp 468-75.

${ }^{28}$ H Schebesta, T Verdonk, K Purnhagen and B Keirsbilck, "Unfair Trading Practices in the Food Supply Chain: Regulating Right?” (2018) 9 European Journal of Risk Regulation 690, 699.

${ }^{29}$ ibid, 700.

${ }^{30}$ P Verbruggen, "Gorillas in the Closet? Public and Private Actors in the Enforcement of Transnational Private Regulation” (2013) 7 Regulation \& Governance 512.

${ }^{31}$ Regulation (EU) No 1169/2011 of the European Parliament and of the Council of 25 October 2011 on the provision of food information to consumers, OJ L 304/18.

${ }^{32}$ Directive 2009/22/EC of the European Parliament and of the Council of 23 April 2009 on injunctions for the protection of consumers' interests, OJ L 110/30.

${ }^{33}$ Keirsbilck, supra, note 27, 468-75.
} 
Private standardisation consists of standard-setting, certification and accreditation the so-called Tripartite Standards Regime. ${ }^{34}$ The regime is a hybrid public-private one, as private parties regularly conduct certification, while accreditation bodies represent a public control element. ${ }^{35}$ In the EU, such public control is exercised by virtue of Regulation (EC) No 765/2008 ("Accreditation Regulation"). The Accreditation Regulation contains several provisions to ensure the impartiality, functioning, objectivity and competence of accreditation bodies. ${ }^{37}$ For voluntary certification schemes for agricultural products and foodstuffs, the Commission issued non-binding best practice guidelines. ${ }^{38}$ According to recommendation 8 of the guidelines, certification bodies should be independent. The scheme's requirements are enforced by private bodies carrying out inspections, which should follow certain minimum standards as stipulated under recommendation 6.2 of the guidelines.

According to the Commission's guidelines, voluntary certification schemes must also be in compliance with EU law, such as that concerning fundamental freedoms, competition and public procurement. ${ }^{39}$ However, the application of these EU law areas to voluntary certification schemes is problematic, as many of these schemes escape their scope of application. ${ }^{40}$ For example, despite the Court of Justice of the European Union (CJEU) having offered some hints, it is still unclear as to how to reconcile the private nature of voluntary certification schemes with the fact that most of the abovementioned EU law areas concern public measures. ${ }^{41}$ In the food sector, most of these schemes are displayed as additional labelling on the food packaging. They qualify as voluntary food information subject to Article 36 FIC in connection with Article 7 FIC and the corresponding enforcement provisions. Taken together with the provisions from Directive 2005/29/EC, ${ }^{42}$ these provisions "impose a positive obligation on food business operators to provide information about the nature of the control that a given scheme is subject to in a way that is clear, i.e. intelligible, unambiguous, not confusing, and easy to understand". ${ }^{43}$

\footnotetext{
${ }^{34}$ H Schebesta, “Control in the Label: Self-Declared, Certified, Accredited?" in P Rott (ed.), Certification - Trust, Accountability, Liability (Berlin, Springer 2019) pp 143, 145.

${ }^{35}$ S Henson and J Humphrey, "Understanding the Complexities of Private Standards in Global Agri-Food Chains as They Impact Developing Countries" (2010) 46 Journal of Development Studies 1628.

${ }^{36}$ Regulation (EC) No 765/2008 of the European Parliament and of the Council of 9 July 2008 setting out the requirements for accreditation and market surveillance relating to the marketing of products and repealing Regulation (EEC) No 339/93, OJ L 218/30.

37 See Schebesta, supra, note 34, 147.

${ }^{38}$ Commission Communication - EU best practice guidelines for voluntary certification schemes for agricultural products and foodstuffs, 2010/C 341/04.

39 ibid, recommendation 3.

${ }^{40}$ On the example of "new approach" products and other certification schemes, see R Neerhof, "The Use of Conformity Assessment of Construction Products by the European Union and National Governments: Legitimacy, Effectiveness and the Functioning of the Union Market" in P Rott (ed.), Certification - Trust, Accountability, Liability (Berlin, Springer 2019) p 73.

41 Case C-171/11 Fra.bo SpA $v$ Deutsche Vereinigung des Gas- und Wasserfaches eV (DVGW) - TechnischWissenschaftlicher Verein ECLI:EU:C:2012:453; C-613/14 James Elliott Construction Limited v. Irish Asphalt Limited ECLI:EU:C:2016:821. See also P Cuccuru, "The Public and Private Sides of Harmonized Standards: James Elliott Construction v. Irish Asphalt: Case C-613/14" (2018) 19 German Law Journal 1399-416; KP Purnhagen, "Voluntary 'New Approach' Technical Standards are Subject to Judicial Scrutiny by the CJEU! - The Remarkable CJEU Judgment 'Elliott' on Private Standards” (2017) 8 European Journal of Risk Regulation 586-98; R van Gestel and H-W Micklitz, "European Integration through Standardization: How Judicial Review Is Breaking Down the Club House of Private Standardization Bodies" (2013) 50 Common Market Law Review 145-81.

${ }^{42}$ Directive 2005/29/EC of the European Parliament and of the Council of 11 May 2005 concerning unfair business-to-consumer commercial practices in the internal market ("Unfair Commercial Practices Directive"), OJ L 149/22.

${ }^{43}$ Schebesta, supra, note 34, 155.
} 


\section{d. Enforcement by technology}

Looking into the future, the potential of private enforcement may increase if it is fuelled by new technologies. These possibilities are mainly discussed under the concept of "technological management", ${ }^{44}$ according to which new technologies and big data may replace law as a regulating force in society. ${ }^{45}$ Properly applied, however, technological management can also be used for law enforcement. Consider the following example: a patient's digital health record notes that a patient has an allergy to nuts. This information is linked to a bonus card with which the patient-customer collects points in a supermarket. If a food business operator forgets to label nuts separately in the list of ingredients, even the trained allergysuffering eye of the customer may overlook that a product contains ingredients that could cause an allergic reaction in them. If there were not only labelling obligations but also reporting obligations of the producer of a product containing allergenic ingredients, information about the allergenic properties of the product could be transferred to a state-operated digital platform. The customer could then be warned at the checkout, right after they scanned the bonus card and before paying, that they are about to buy a product to which they are allergic. They could also be informed of this separately on a printed copy of a bill. Of course, this would no longer meet the food information requirements, as this information would be provided after the purchase. Nevertheless, if one accepts the potential offered by technological management, many new ways of combining private and public enforcement are conceivable in the future.

\section{What is an optimal mix of private and public enforcement? Insights from other areas of law and the economic analysis of law}

The basis of the academic discussion of an optimal design of enforcement is the doctrine that substantive rights are meaningless unless they are associated, as it were, with an effective enforcement mechanism. ${ }^{46}$ In the economic analysis of law, to which this paper subscribes, enforcement does not only have a compensatory role. Rather, it is understood to have an effective deterrent effect that offers an incentive to comply with legal rules. ${ }^{47}$ Efficient enforcement follows the maxim of minimising the costs of a legal violation for society as a whole, including the costs of enforcement. ${ }^{48}$ Article 17(2) subparagraph 3 of the General Food Law, which prescribes the measures and penalties needed to be "effective, proportionate and dissuasive", reflects this understanding of efficient enforcement. Article 139(1) sentence 2 of the Control Regulation and Article 6(1) subparagraph 2 of the UTP Directive prescribe similar requirements. The Control Regulation specifies what is meant by "dissuasive" within its scope of application: financial penalties must "reflect, in accordance with national law, at least either the economic advantage for the operator or, as appropriate, a percentage of the operator's turnover". ${ }^{49}$ This provision underscores that the economic analysis of law is an appropriate method for examining the effectiveness of the enforcement of EU food law. It also raises the question of how people are motivated to enforce law.

\footnotetext{
${ }^{44} \mathrm{R}$ Brownsword, Law, Technology and Society: Reimagining the Regulatory Environment (London, Routledge 2019) pp 3-36.

45 ibid, 181-204.

${ }^{46}$ Weber and Faure, supra, note 10, 526.

${ }^{47}$ G Becker, "Crime and Punishment: An Economic Approach" (1968) 76 Journal of Political Economy 169-217; S Shavell, Foundations of Economic Analysis of Law (Cambridge, MA, Harvard University Press 2004) p 515; A Ogus, "Enforcing Regulation: Do We Need the Criminal Law?" in H Sjörgen and G Skogh (eds.), New Perspectives on Economic Crime (Cheltenham, Edward Elgar 2004) pp 42, 46; Weber \& Faure, supra, note 10, 526, 528.

${ }^{48}$ W Allen, "Commentary on the Limits of Compensation and Deterrence in Legal Remedies" (1997) 60 Law \& Contemporary Legal Problems 67, $68 \mathrm{f}$.

${ }^{49}$ Art 139(1) of the Control Regulation.
} 
The spectrum of possible behaviours is wide; there are those who refrain from law enforcement even though the law was violated. This is the case when it is not "worthwhile" to enforce the law because only a small damage occurred and the enforcement costs are high. ${ }^{50}$ This is called "rational apathy". ${ }^{51}$ For example, if we buy an apple and later realise that it is no longer edible, then we will probably dispose of the apple, even though we might have the right to exchange it in the shop. Such rational apathy is especially problematic when the damage to an individual is small but society sustains significant damage. ${ }^{52}$ If the reason for the apple being inedible is a structural problem in the supply chain that could affect all apples, more effective enforcement on behalf of the community is warranted. The extent to which the right of private enforcement is used also depends on cultural conditions. For example, research has shown that postcommunist EU Member States traditionally rely more on public enforcement as compared to private enforcement. ${ }^{53}$

Moreover, private entities may refrain from taking legal action if they do not have sufficient information to determine whether the action will be successful. Such an information deficit is an important aspect of law enforcement because private entities cannot avail of the same possibilities to obtain enforcement-relevant information as public authorities. ${ }^{54}$ The far-reaching control powers of public authorities, such as those contained in Article 14 of the Control Regulation, are not available to private entities. By means of a request under national right of information laws, private entities may be able to obtain relevant information, but only if it has been previously collected by a public authority.

Finally, fear has been identified as a factor (the so-called "fear factor") in business decision-making concerning private enforcement in the supply chain. The UTP Directive explains the shift from private to public enforcement of B2B unfair trading practices by stating that "[w] here reliance on contract law or self-regulatory initiatives is possible, fear of commercial retaliation against a complainant, as well as financial risks involved in challenging such practices, limit the practical value of those forms of redress". ${ }^{55}$ In other words, smaller businesses in a supply chain structure fear exclusion from the chain should they use private enforcement to defend themselves against their more powerful trading partners.

This perspective seems to favour public enforcement; however, even public enforcement faces several obstacles. First, the resources (financial, human, knowledge) available to a public authority for enforcement purposes may significantly influence its effectiveness. ${ }^{56}$ Even if resources are optimal, public officials may still decide not to enforce, often for understandable reasons, with the most cited reason being so-called "regulatory capture". ${ }^{57}$ According to its broad definition, regulatory capture describes "the process through which special interests affect state intervention in any of its forms, which can include areas as diverse as the setting of taxes, the choice of foreign or monetary policy, or the legislation affecting R\&D". ${ }^{58}$ Employees of public authorities also pursue vested

\footnotetext{
${ }^{50}$ W Landes and R Posner, "The Private Enforcement of Law" (1975) 4 Journal of Legal Studies 33.

${ }^{51}$ F Weber, “Gegenwärtige Verbraucherrechtsfälle und Bedarf an staatlicher Rechtsdurchsetzung” (2013) 28 Verbraucher und Recht 323, 325.

${ }^{52}$ Landes and Posner, supra, note 50, 1, 33.

53 On the example of Poland, see M Safjan, L Gorywoda and A Janczuk-Goriwoda, "Taking the Collective Interest of Consumers Seriously: A View from Poland" in F Cafaggi and H Micklitz (eds), New Frontiers of Consumer Protection: The Interplay Between Private and Public Enforcement (Cambridge, Intersentia 2009) pp 171, 193.

${ }^{54}$ Weber and Faure, supra, note 10, 538.

${ }^{55}$ Recital 8 UTP Directive.

${ }^{56}$ Weber, supra, note 51, 323, $327 \mathrm{f}$.

${ }^{57}$ G Stigler, "The Theory of Economic Regulation” (1971) 2 Bell Journal of Economics and Management Science $3-18$.

${ }^{58}$ E dal Bó, "Regulatory Capture: A Review” (2006) 22 Oxford Review of Economic Policy 203.
} 
interests, such as climbing the internal career ladder, salary increases or finding a job outside of public administration. ${ }^{59}$ For this reason, as some authors argue, public officials are motivated to extensively cooperate with private entities, such as food business operators. ${ }^{60}$ For EU food law, however, such closeness to industry may not automatically mean an illegitimate vested interest, as Recital 39 of the Control Regulation clarifies that competent Member State authorities act both "in the interest of operators and of the general public". Additionally, problems of capture and vested interests can often be resolved by not allowing individual authorities to become too powerful. ${ }^{61}$ If competences are distributed between several authorities, the possible effects of capture and vested interests may be reduced. ${ }^{62}$ A similar effect can be achieved via regulator audits inside public authorities.

There are also regulatees who attempt to enforce the law for motives other than justice and the protection of legal interests. Frivolous enforcement, notably the emergence of the "litigation industry", has been subject to repeated criticism. ${ }^{63}$ The unrealistic promises of the litigation industry only leave plaintiffs disappointed and public authorities and courts potentially overburdened. ${ }^{64}$ Even in the situation of the overburdening of courts and public authorities, a state must ensure that the institutions responsible for law enforcement are properly functioning and adequately equipped. ${ }^{65}$ Sometimes private litigants are not primarily motivated to enforce rights or obligations, but rather to make "noise" and attract media attention or financing - motives that are ultimately different from the objectives of achieving justice and legal protection. ${ }^{66}$ In some cases, despite the incongruity between private enforcement motives and enforcement policy objectives, rights may receive effective protection and obligations may be effectively fulfilled. The effect, however, may be the opposite, too: the litigation industry, fuelled by the availability of collective redress mechanisms, may impede effective law enforcement and raise its cost. ${ }^{67}$ This includes legal actions that are taken solely to harm a competing food business operator. One way to try to counteract frivolous enforcement is to endow specific organisations or legal professionals with a privileged right to sue. But even then there is no guarantee that frivolous legal enforcement will not occur. Ultimately, the legislature and legal practitioners are also called upon to create an appropriate legal framework and legal culture to effectively prosecute legal actions of the same class that are expected in a modern society. ${ }^{68}$ An efficient mix of private and public enforcement is not easy to achieve. Both types of enforcement have their advantages and disadvantages, and an effective mix can be effectively examined only upon a closer look at different determinants.

Outside the core area of food law, we also find a well-thought-out mix of private and public enforcement; for example, breaches of food information law in the EU can be

\footnotetext{
${ }^{59}$ See JR Simmons, “Altruistic Corruption: The Downsian Bureaucrats Revised” (1999) 21(3) Administrative Theory \& Praxis 265-79.

${ }^{60}$ For a critical note, see S Horel, “Unhappy Meal. The European Food Safety Authority's Independence Problem" (Corporate Europe Observatory 2013) < https://corporateeurope.org/en/efsa/2013/10/unhappy-mealeuropean-food-safety-authoritys-independence-problem $>$ (last accessed 25 October 2021).

${ }^{61}$ Weber, supra, note 51, 323, 326.

62 ibid.

63 ibid, 323, 325. See also P Steinert, "Der deutsche Diesel unter Generalverdacht - ein Sachstandsbericht zum Abgasskandal" (2021) Straßenverkehrsrecht 41.

${ }^{64}$ To date, a risk of overburdening has not been proven in court; see examples from Germany VG Augsburg Urt. v. 19.11.2019 - 1 K 19.1255, BeckRS 2019, 31097, para 30; VGH München Beschl. v. 7.8.2020 - 5 CS 20.1302, BeckRS 2020, 20595, para 30.

${ }^{65}$ VG Frankfurt a. M. Beschl. v. 12.12.2019 - 5 L 3285/19, Beck RS 2019, 34984, Rn. 38.

${ }^{66}$ M Heese, "Klageindustrie?" (2021) 9 Neue Juristische Wochenschrift 6.

67 ibid, 6.

68 ibid.
} 
enforced via class (representative) actions. ${ }^{69}$ An individual consumer would most probably not sue when they notice that a food package is not designed in accordance with food information law. Therefore, representative actions constitute an adequate means of law enforcement. In areas of information asymmetry between food business operators, other market players and public authorities, food law also provides for special information mechanisms. This is the case concerning novel foods and GMO foods where authorisation procedures ensure that food information is effectively communicated to the authorities, who can then decide on special post-marketing monitoring and supervision measures. ${ }^{70}$

The cost of enforcement is the key determinant of whether a food business operator avails of means of private enforcement. ${ }^{71}$ Businesses calculate carefully whether to use private enforcement based on a cost/benefit ratio. Costs include costs for legal representation, court fees, costs associated with the preservation of evidence and time. Benefits include, for example, monetary or reputational gains. Businesses also consider the probabilities of success. In Germany, for example, it is argued that the lack of a legal framework for taking class actions diminishes the success of private enforcement (ie individual actions). ${ }^{72}$ Rather, since small claims cannot be bundled together to make their litigation financially more attractive, legal professionals are disincentivised to represents clients in such cases en masse. ${ }^{73}$ Therefore, if the costs outweigh the benefits (or the probability thereof), claimants behave in rational apathy and individually decide against enforcement. ${ }^{74}$ To prevent this, several options are proposed to strengthen private enforcement. If only individual cases can be brought before a court, rational apathy can be overcome by legal expenses insurance, legal aid or legislating for the possibility to take collective or representative actions. $^{75}$

If a damage is greater, affecting society at large, public enforcement measures are generally preferred. ${ }^{76}$ In such cases, the costs of enforcement and the risks of loss are borne by the public. However, it is difficult to determine how the relevant authorities can receive information of possible infringements. Therefore, notification mechanisms prompting an official action are proposed in the literature. Someone must give the authorities a "hint", making effective public enforcement contingent upon private initiatives. However, even here, the "rational apathy" problem of private enforcement arises. If both private and public enforcement options are available, a food business operator may decide to avoid private enforcement and "convince" - potentially anonymously - public authorities to act against its

\footnotetext{
${ }^{69}$ Directive (EU) 2020/1828 of the European Parliament and of the Council of 25 November 2020 on representative actions for the protection of the collective interests of consumers.

${ }^{70}$ Per Art 24 of Regulation (EU) 2015/2283 of the European Parliament and of the Council of 25 November 2015 on novel foods, "[t]he Commission may, for food safety reasons and taking into account the opinion of the Authority, impose post-market monitoring requirements. Such requirements may include, on a case-by-case basis, the identification of the relevant food business operators". As for GMO food, per Regulation (EC) No 1829/2003 of the European Parliament and of the Council of 22 September 2003 on genetically modified food and feed, the application for authorisation should contain a proposal for post-marketing monitoring regarding use of the food for human consumption. In addition, a monitoring plan for environmental effects should be submitted. The outcome of the risk assessment should determine any post-market monitoring requirements. Where post-market monitoring has been imposed on the authorisation-holder, the authorisation-holder shall ensure that it is carried out and shall submit monitoring reports to the Commission in accordance with the terms of the authorisation (Art 9(1) therein).

${ }^{71}$ Weber and Faure, supra, note 10, 533.

${ }^{72}$ Heese, supra, note 66, 6 .

73 ibid.

${ }^{74}$ Weber and Faure, supra, note 10, 530.

${ }^{75}$ L Visscher and T Schepens, "A Law and Economics Approach to Cost Shifting, Fee Arrangements and Legal Expense Insurance” in M Tuil and L Visscher (eds), New Trends in Financing Civil Litigation in Europe. A Legal, Empirical, and Economic Analysis (Cheltenham, Edward Elgar 2010) pp 7-32.

${ }^{76}$ See R Schaub, "Streuschäden im deutschen und europäischen Recht" (2011) 66 Juristenzeitung 13.
} 
competitors. The "tipper" will only do so if the benefits outweigh the costs. For example, an anonymous notification may mitigate the fear factor that could otherwise restrain businesses from taking effective legal action. In addition, special protection of whistle-blowers can incentivise "tippers" to notify. For example, Article 140 of the Control Regulation, considered in the context of the Whistleblower Directive, ${ }^{77}$ provides special protection for whistle-blowers who report infringements to authorities.

Better possibilities for authorities to obtain information can justify the use of public enforcement. ${ }^{78}$ Especially in times of increasing digitalisation, it may be easier for public authorities to obtain the relevant data on supply chains in order to prosecute infringements. ${ }^{79}$ Private individuals often do not have these possibilities. Moreover, as technological management demonstrates, public enforcement can surpass the limits of official administrative procedures, and it can also take place via technical means. A food safety authority may work as a data platform that brings different users together, supports them in their own enforcement and monitors the fair collection, processing and use of data.

The main disadvantages of private enforcement are rational apathy, information asymmetry and the fear factor. These may be resolved by public enforcement, provided capture effects are avoided and sufficient resources and notification mechanisms are ensured. To that effect, EU food law offers a thoroughly modern solution: food business operators must themselves notify the competent authorities in cases listed in Article 19 of the General Food Law.

\section{How can these findings be applied to EU food law?}

EU food law also serves as a model for other areas of law regarding an effective enforcement mix. First, Article 17(2) of the General Food Law establishes the primacy of public enforcement at the level of Member States, thereby addressing the problem of rational apathy. At the same time, by qualifying enforcement as "effective, proportionate and dissuasive", it also tasks Member States to address the resource problem of effective enforcement. It is obvious that in practice this creates a variety of enforcement regimes throughout the Union. ${ }^{80}$ Economically stronger Member States, for example, will find it easier to devote the necessary resources to effective public enforcement. In addition, where the costs of litigation are high relative to a country's GDP per capita, enforcement has a different effect compared to countries where such costs are lower.

However, it is difficult to undertake any practical comparison in this regard. As the Commission noted, the data presented in the annual reports of official control bodies have varied greatly. The Control Regulation, effective since 2019, attempted to remedy this problem by introducing a standard form for the annual reports. However, new data are not yet available, as the latest of the Commission's reports covering the period of 2017-2018 was only published in May 2021. ${ }^{81}$ Significant delays in the reports' submission are surely to blame: only six Member States submitted their annual reports within the deadline. Nonetheless, this report from the Commission contains certain important

\footnotetext{
${ }^{77}$ Directive (EU) 2019/1937 of the European Parliament and of the Council of 23 October 2019 on the protection of persons who report breaches of Union law, PE/78/2019/REV/1, OJ L 305/17.

${ }^{78}$ Weber and Faure, supra, note 10.

79 ibid.

${ }^{80}$ For unfair competition law, see Keirsbilck, supra, note 27, 468-75; for the enforcement of health claims, see A de Boer, M Urlings, E Vos and A Bast, "Enforcement of the Nutrition and Health Claim Regulation" (2015) 10 European Food and Feed Law Review 334-44.

${ }^{81}$ European Commission, Report on the overall operation of official controls performed in Member States (2017-2018) to ensure the application of food and feed law, rules on animal health and welfare, plant health and plant protection products (2019) <https://op.europa.eu/en/publication-detail/-/publication/5254ff4eb203-11eb-8aca-01aa75ed71a1> (last accessed 25 October 2021).
} 
insights. It notes that Member States fail to clearly define strategic objectives in their multi-annual national control plans, thereby making it impossible to decide which indicators to measure. Another problem appears to be a lack of methodological rigour in determining risk-based priorities according to which national authorities should plan their official controls. For example, some Member States use information from private quality assurance schemes to inform their risk assessments. The Commission's report also notes that several Member States experienced budget cuts that resulted in reduced staffing levels and material resources. This has happened even though the control of some food safety risks (such as the African swine fever epidemic) requires significantly more resources than others (such as microbiological safety). As a result, activities planned in the multi-annual national control plans could not be fulfilled. In some Member States, as a mitigation strategy, data analysis and information technologies were employed to compensate for staffing shortages.

Comparing data from the annual reports, such as the number of instances of noncompliance, can be a problematic exercise. High non-compliance numbers may either indicate a bad food safety situation or may be equally understood as involving the employment of a more effective control mechanism. In other words, any self-reporting on official controls by national authorities must be contextualised, but the precise data for contextualising, and for better understanding the resource problem, are not available. Additional auditing of official control outputs may contribute to better contextualising of the effectiveness of official controls. Nonetheless, the narrative behind the revealed non-compliance points to the same common causes: a lack of understanding of legal requirements on the side of food business operators, high staff turnover and insufficient training and resources to bring food business operations into compliance. In response, Member States provide guidance, lead information and awareness campaigns and organise training. In the experience of official control bodies, enhanced knowledge leads to greater compliance rates. ${ }^{82}$

Regular official and risk-based controls, which are carried out unannounced and according to the rules of the multi-annual national control plans, ${ }^{83}$ create an incentive for food business operators to take their control and reporting obligations seriously. If an infringement is detected during these controls, severe sanctions may be applied, ranging from a mere "classification" 84 to an imposition of a penalty of an amount at least equal to the economic advantage for the food business operator or, if applicable, set as a percentage of the food business operator's turnover. ${ }^{85}$ If sanctions are imposed, a food business operator is likely to suffer a reputation or revenue loss. Most businesses affected by sanctions ended in insolvency. ${ }^{86}$ It may therefore be less costly for food business operators to immediately comply with their obligation to notify and withdraw. Measures of public enforcement are therefore not an end in themselves, but rather provide for the effective application of private enforcement as laid down in Article 19 of the General Food Law. Sanctions may motivate food business operators to privately enforce their obligations. The system is designed in such a way that authorities would ideally exercise control at regular risk-based control intervals and react if they receive further notifications of potential infringements.

\footnotetext{
82 ibid.

${ }^{83}$ See Art 9 of the Control Regulation.

${ }^{84}$ Art 11(3) of the Control Regulation. As an example from practice of the case of the veterinary office BerlinPankow, which published a negative list of businesses on the Internet, and for legal discussions of these cases, see M Tsambikakis and R Wallau, "Moderner Pranger: Die sog. Negativliste von Pankow - Verbraucherinformation auf Kosten des Beschuldigten?” (2010) Strafverteidiger Forum 177; M Böhm, M Lingenfelder and W Voit, "Verbraucherinformation auf dem Prüfstand" (2011) Neue Zeitschrift für Verwaltungsrecht 198, 201.

${ }^{85}$ Art 139 of the Control Regulation.

${ }^{86}$ See, eg, the facts of Case C-636/11 Berger v Bayern, ECLI:EU:C:2013:227, para 23.
} 


\section{Conclusion}

EU food law establishes a modern and forward-looking mix of private and public enforcement. The various EU food law instruments largely ensure a resource-efficient and effectively coordinated mix. However, in trying to achieve a practical implementation of such an effective mix, the realities of the European internal market must be considered. Moreover, new technologies have the potential to stimulate a novel enforcement mix. In this area, public authorities could become data platform operators, while consumers as users of these platforms enforce their rights themselves via their behaviour. To harness the technological potential of a novel enforcement mix, it is important to understand the finely tuned system of private and public law enforcement and to make improvements where needed.

Competing interests. The authors declare none.

Cite this article: KP Purnhagen and A Molitorisová (2022). "Public and Private Enforcement in European Union Food Law”. European Journal of Risk Regulation 13, 464-476. https://doi.org/10.1017/err.2021.59 